\title{
Clay Mineral Composition and Diagenesis: Effects on the Location and Behavior of Faults in the Frontal Portions of Subduction Zones
}

by Michael B. Underwood

doi:10.2204/iodp.sd.s01.19.2007

One of the more ambitious goals of the Seismogenic Zone Experiment (SEIZE) is to discriminate between the effects of changing intrinsic frictional strength (i.e., gouge versus wall-rock) and the effects of gradual or transient increases in pore pressure within fault zones. In subduction zones, both variables are likely to change with increasing distance down the plate boundary. In addition to sediment's cohesion and coefficient of internal friction, the shear strength of any given stratigraphic interval depends upon fluid pressure and total normal stress. The release of fluids from mudstones during diagenesis (including volatiles generated from organic matter) is modulated by a combination of mechanical compaction, tectonic consolidation, and mineral reactions. Thus, it is essential to determine how permeability, sedimentderived fluid sources, and fluid flow contribute to overpressure conditions within the subduction inputs, beginning seaward of the subduction front at depths of $2500 \mathrm{~m}$ or less.

Primary lithostratigraphic architecture exerts a firstorder influence over the material properties and tectonic behavior of subduction zones, at least near the toe of the margin wedge. Generic sedimentary facies models for trenches (Piper et al., 1973) show upward thickening and coarsening trends (from basalt at the base through pelagic ooze, hemipelagic mud, silty turbidites, and sandy turbidites). As glaring exceptions to that norm, however, there are substantial thicknesses of highly permeable sand (abyssalplain deposits) that continue to move down the subduction path (i.e., beneath the frontal décollement) in Nankai (Ashizuri transect), Barbados, and Cascadia (Underwood and Moore, 1995; Underwood, 2007). Until those sands are lithified by cementation, their high net permeability will control three-dimensional patterns of fluid circulation. The amount and types of clay-size particles within each stratigraphic interval are also important because they affect any sediment's coefficient of friction and permeability. Empirical and experimental studies demonstrate that clay-rich fault gouges are weaker than surrounding wall rocks, typically because of their constituent particle size and mineralogy. Expandable minerals of the smectite group (e.g., montmorillonite) are notorious in the eyes of geotechnical engineers for affecting strata's coefficient of internal friction, compressibility, and permeability (Lupini et al., 1981; Morrow et al., 1992; Saffer and Marone, 2003). Common hydrous minerals (e.g., smectite and opal) also
increase fluid production

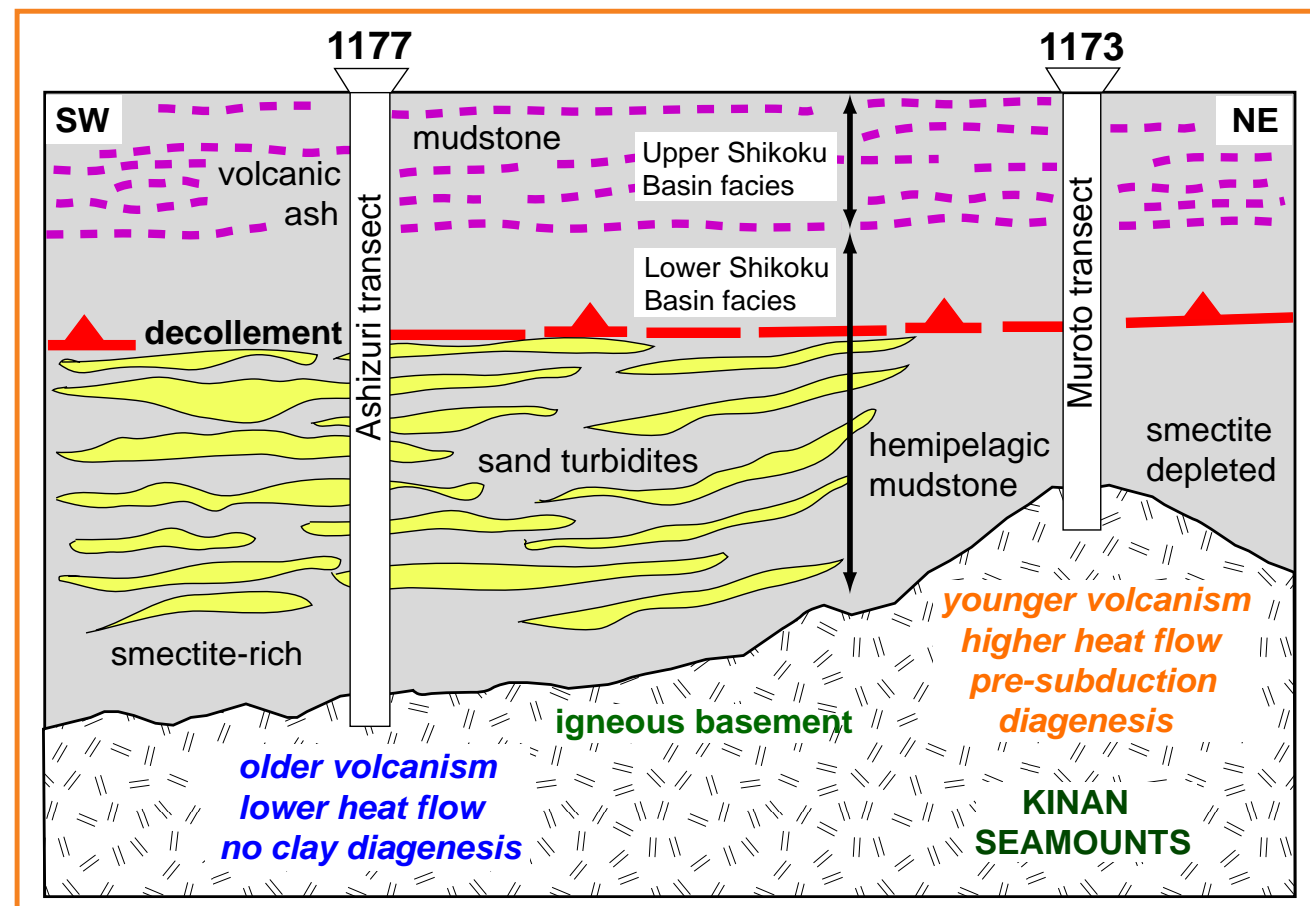

Figure 1. Schematic cross-section through ODP Sites 1177 and 1173 near the subduction front of the Nankai Trough. The plane of the section is oriented parallel to the strike of the margin and shows pinch-out of Miocene to Pliocene turbidites against the paleo-seafloor and basement relief of the Kinan seamounts. during diagenesis. Fluids produced from dehydration reactions become increasingly important as the burial temperature increases and the pore volume is reduced by compaction. To complicate matters further, the thermal structure of subducting lithosphere varies with crustal age, basement relief, and patterns of hydrothermal circulation. The zones of maximum fluid production, therefore, should shift spatially in response to variations in two independent input parameters: heat flow and abundance ofhydrous minerals. Moreover, pathways of focused fluid migration will track the architecture of high-permeability sand bodies inherited from the depositional 


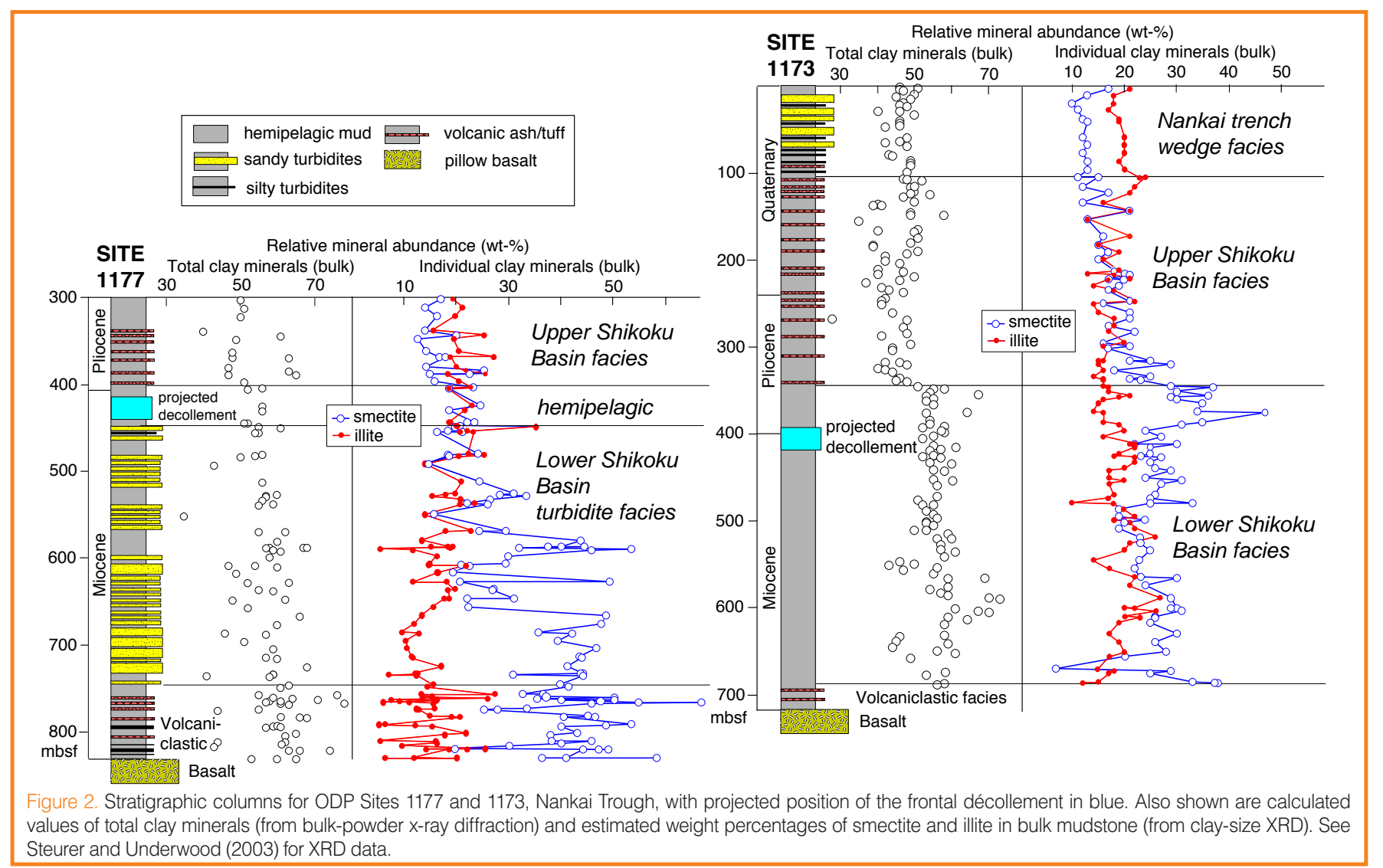

environment (i.e., isolated shoe-string channel sands, stacked channel-levee complexes, unconfined sand sheets, depositional lobes). Compartments of excess pore-fluid pressure are, in many depositional systems, set up initially by those sand-body geometries (Bredehoeft et al., 1988; Flemings et al., 2002). Conversely, if subduction inputs consist of low-permeability mud throughout a system, then diffuse drainage will be retarded, and focused flow is more likely to follow structural conduits of fracture-enhanced permeability.

When investigating the change from stable sliding to stick-slip behavior, the "smectite-to-illite hypothesis", in its elementary form, provides scientists with a tractable idea to test (Hyndman et al., 1997; Vrolijk, 1990). But that influential concept is oversimplified because it does not take into account three-dimensional variations in lithostratigraphy, either within or among individual subduction margins. Similarly, the hypothesis fails to account adequately for local and global variability in total clay abundance, the absolute amount of smectite, grain fabric, pore pressure, heat flow, and reaction progress prior to subduction. A more holistic view, stressed by Moore and Saffer (2001), is that several interrelated factors and processes (e.g., precipitation of carbonate and silicate cements, progressive growth of phyllosilicates, clay-mineral dehydration, changes in frictional properties of clay) act collectively to modulate the strength and mechanical behavior of strata on opposite sides of the updip limit of the seismogenic zone. The recipe for blending each factor and process almost certainly changes from one subduction margin to another, within each individual margin, and through time. This natural variability needs to be taken into account when drilling projects target subduction thrusts.

Variability in subduction inputs can lead to substantial differences in how quickly diagenetic reactions progress, both outboard of a subduction front and downdip along the subduction path. This effect is particularly obvious in the Nankai Trough, where heat flow varies with distance from the fossil spreading ridge of the Shikoku Basin (Yamano et al., 2003). Inputs of sediment to the Nankai Trough change in three dimensions because irregular basement highs deflected turbidity currents during early stages of abyssalfloor sedimentation. Sandy turbidites are the norm, rather than the exception, beneath the frontal décollement where smooth basement enters the subduction zone (Fig. 1). The content of smectite also changes along strike in Nankai because of local perturbations of heat flow and pre-subduction clay diagenesis (Fig. 2). By the time strata pass beneath the toe of the warmer Muroto accretionary prism, the smectiteto-illite reaction advances nearly to completion at the sediment-basalt interface (Fig. 2). In contrast, coeval strata within the nearby (cooler) Ashizuri transect remain virtually unaltered. Accurate predictions of where and how much fluid volume might be released through deeper dehydration reactions demand accurate three-dimensional knowledge of the starting materials and thermal structure.

Each subduction margin around the world displays its own idiosyncrasies. The frontal décollement in the Barbados accretionary prism occupies a stratigraphic interval that is 
highly enriched in smectite (Deng and Underwood, 2001). This unusually high concentration of smectite contributes to the décollement's intrinsic weakness, and downdip fluid production probably leads to fluid overpressures. In comparison, the Costa Rica segment of the Middle America Trench is starved of terrigenous sediment, so igneous basement there is overlain successively by open-ocean calcareous ooze and diatomaceous smectite-rich hemipelagic mud (Spinelli and Underwood, 2004). Numerical simulations indicate that spatial variations in the thermal structure of the Cocos plate lead to changes in diagenetic reaction progress, fluid production, pore pressure, and effective stress, both within and beneath the plate boundary (Spinelli et al., 2006). This degree of thermal variability creates additional challenges for fault-zone drilling projects; lessons extracted from one system or one borehole cannot be imported into another.

\section{References}

Bredehoeft, J.D., Djevanshir, R.D., and Belitz, K.R., 1988. Lateral fluid flow in compacting sand-shale sequence: South Caspian Sea. Am. Assoc. Petrol. Geol. Bull., 72:416-424.

Deng, X. and Underwood, M.B., 2001. Abundance of smectite and the location of a plate-boundary fault, Barbados accretionary prism. Geol. Soc. Am. Bull., 113:495-507, doi:10.1130/00167606(2001)113<0495:AOSATL >2.0CO;2.

Flemings, P.B., Stump, B.B., Finkbeiner, T., and Zoback, M., 2002. Flow focusing in overpressured sandstones: Theory, observations, and applications. Am. J. Sci., 302:827-855, doi:10.2475/ajs.302.10.827.

Hyndman, R.D., Yamano, M., and Oleskevich, D.A., 1997. The seismogenic zone of subduction thrust faults. Island Arc, 6:244 260, doi:10.111/j.1440-1738.1997.tb00175.x.

Lupini, J.F., Skinner, A.E., and Vaughan, P.R., 1981. The drained residual strength of cohesive soils. Geotechnique, 31:181213.

Moore, J.C. and Saffer, D.M., 2001. Updip limit of the seismogenic zone beneath the accretionary prism of southwest Japan: An effect of diagenetic to low-grade metamorphic processes and increasing effective stress. Geology, 29:183-186, doi:10.1130/0091-7613(2001)029<0183:ULOTSZ >2.0CO;2.

Morrow, C., Radney, B., and Byerlee, J., 1992. Frictional strength and the effective pressure law of montmorillonite and illite clays. In Evans, B., and Wong, T.F. (Eds.), Fault Mechanics and Transport Properties of Rocks. San Diego (Academic Press), $69-88$.

Piper, D.J.W., von Huene, R., and Duncan, J.R., 1973. Late Quaternary sedimentation in the active eastern Aleutian Trench. Geology, 1:19-22.

Saffer, D.M. and Marone, C., 2003. Comparison of smectite- and illiterich gouge frictional properties: application to the updip limit of the seismogenic zone along subduction megathrusts. Earth Planet. Sci. Lett., 215:219-235, doi:10.1016/ S0012-821X(03) 00424-2.

Spinelli, G.A. and Underwood, M.B., 2004. Character of sediments entering the Costa Rica subduction zone: Implications for partitioning of water along the plate interface. Island Arc, 13:432-451, doi:10.1029/2004JB003436.
Spinelli, G.A., Saffer, D.M., and Underwood, M.B., 2006. Hydrogeologic responses to three-dimenional temperature variability, Costa Rica subduction margin. J. Geophys. Res., 111:B04403, doi:10.1029/2004JB003436.

Steurer, J.F. and Underwood, M.B., 2003. Clay mineralogy of mudstones from the Nankai Trough reference sites 1173 and 1177 and frontal accretionary prism site 1174. In Mikada, H., Moore, G.F., Taira, A., Becker, K., Moore, J.C., and Klaus, A. (Eds.), Proc. ODP, Sci. Results, 190/196, College Station, Texas (Ocean Drilling Program) 1-37, doi:10.2973/ odp.proc.sr.190196.211.2003.

Underwood, M.B., 2007. Sediment inputs to subduction zones: Why lithostratigraphy and clay mineralogy matter. In Dixon, T., and Moore, J.C. (Eds.), The Seismogenic Zone of Subduction Thrust Faults. New York (Columbia University Press), in press.

Underwood, M.B. and Moore, G.F., 1995. Trenches and trench-slope basins. In Busby, C.J., and Ingersoll, R.V. (Eds.), Tectonics of Sedimentary Basins. Malden, Mass. (Blackwell Science), 179-219.

Vrolijk, P., 1990. On the mechanical role of smectite in subduction zones. Geology, 18:703-707, doi:10.1130/00917613(1990)018<0703:OTMROS>2.3.CO;2.

Yamano, M., Kinoshita, M., Gato, S., and Matsubayashi, O., 2003. Extremely high heat flow anomaly in the middle part of the Nankai Trough. Phys. Chem. Earth, 28:487-497.

\section{Author}

Michael B. Underwood, Department of Geological Sciences, University of Missouri, Columbia, Mo., 65203, U.S.A., e-mail: UnderwoodM@missouri.edu. 